\title{
Reduced compartmental model of the periglomerular cell of the mammalian olfactory bulb
}

\author{
Denise Arruda*1, Rodrigo Publio ${ }^{2}$ and Antonio C Roque ${ }^{1}$
}

\author{
Address: ${ }^{1}$ Laboratory of Neural Systems, Department of Physics and Mathematics, School of Philosophy, Sciences and Letters of Ribeirão Preto, \\ University of São Paulo, 14040-901 Ribeirão Preto, SP, Brazil and ${ }^{2}$ Computational Neuroscience Unit, Okinawa Institute of Science and \\ Technology, 7542 Onna, Onna-son, Okinawa 904-0411, Japan \\ Email: Denise Arruda* - denisearruda84@gmail.com \\ * Corresponding author
}

from Eighteenth Annual Computational Neuroscience Meeting: CNS*2009

Berlin, Germany. 18-23 July 2009

Published: 13 July 2009

BMC Neuroscience 2009, I0(Suppl I):P43 doi:I0.I I86/I47I-2202-I0-SI-P43

This abstract is available from: http://www.biomedcentral.com/I47I-2202/I0/SI/P43

(c) 2009 Arruda et al; licensee BioMed Central Ltd.

The periglomerular (PG) cells constitute a class of interneurons of the glomerular layer of the olfactory bulb (OB). They have small cell bodies and short spiny dendrites, which make reciprocal dendrodendritic synapses with primary dendrites of mitral and tufted $(\mathrm{m} / \mathrm{t})$ cells within glomeruli $[1,2]$. The functional roles of PG cells are not known but their connectivity pattern suggest important functions for them in odor processing $[3,4]$. This work describes a reduced compartmental, Hodgkin-Huxley type model of the PG cell. It was made to be embedded in an OB model, so it has specific compartments for synaptic inputs from olfactory receptor neurons and dendrodendritic synapses with $\mathrm{m} / \mathrm{t}$ cells. The model was constructed using NEURON [5]. It has a five-compartment structure, with a soma connected to two dendrites (primary and secondary) and an axon, with the primary dendrite having a spine connected to its distal end. The dimensions and passive membrane properties of the compartments were based on data from the literature $[1,2]$. Six different ionic currents were used (the compartments in which they appear are within parentheses): HodgkinHuxley sodium and potassium (soma and axon), A-type inactivating current (soma, dendrites and spine), delayed rectifier potassium current (soma, dendrites and spine), hyperpolarization-activated current (soma, dendrites and spine) and low-threshold T-type calcium current (soma, dendrites and spine). The model also has a calcium diffusion mechanism in the soma, dendrites and spine. The maximal conductance densities were adjusted both manually and automatically using the Neurofitter package [6]. An auto-inhibition was also implemented in the model via a graded GABAergic autosynapse in the spine. The model was submitted to simulated experiments that mimic experimental protocols [2] and reproduced the results well (see Figure 1, which should be compared with Figure $1 \mathrm{C}$ from [2]). This indicates that the model can be used in OB models.

\section{Acknowledgments}

We would like to thank Michelle Lilith and the organizers of the Advanced Course in Computational Neuroscience, Arcachon, France, August 6-31 2007, where this work begun. ACR is supported by a research grant from CNPq.

\section{References}

I. Pinching AJ, Powell TPS: The neuron types of the glomerular layer of the olfactory bulb. J Cell Sci 1971, 9:305-345.

2. McQuiston AR, Katz LC: Electrophysiology of interneurons in the glomerular layer of the rat olfactory bulb. J Neurophysiol 2001, 86: 1899-1907.

3. Schoppa NE, Urban NN: Dendritic processing within olfactory bulb circuits. TINS 2003, 26:50I-506.

4. Cleland TA, Sethupathy P: Non-topographical contrast enhancement in the olfactory bulb. BMC Neuroscience 2006, 7:7.

5. Carnevale NT, Hines ML: The NEURON Book Cambridge, UK, Cambridge University Press; 2006.

6. Van Geit W, Achard P, De Schutter E: Neurofitter: a parameter tuning package for a wide range of electrophysiological neuron models. Front Neuroinformatics 2007, I:I. 


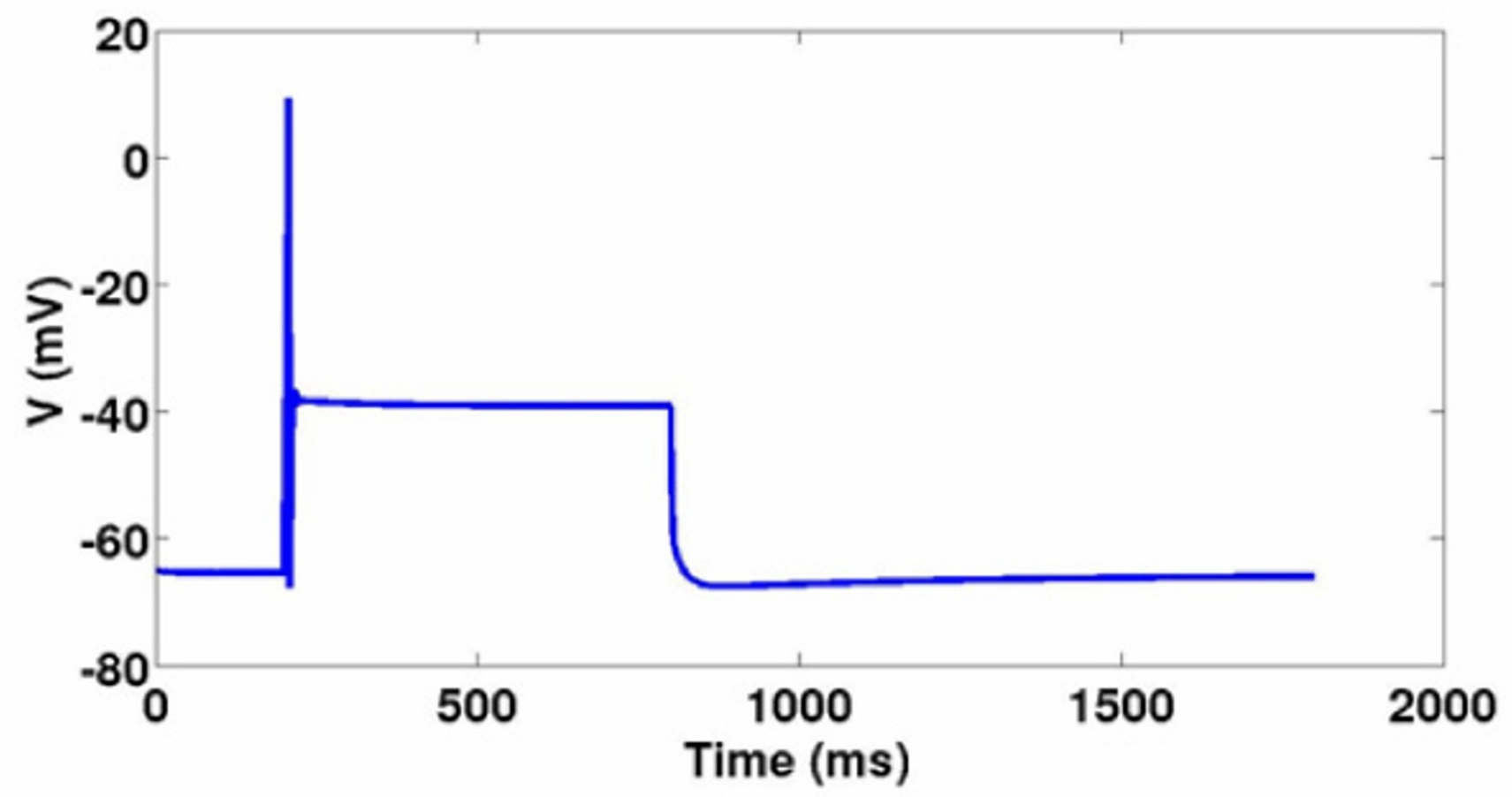

Figure I

Response of the model to a current step of $0.1 \mathrm{nA}$ applied with a $200 \mathrm{~ms}$ delay for a $600 \mathrm{~ms}$ duration.

Publish with Biomed Central and every scientist can read your work free of charge

"BioMed Central will be the most significant development for disseminating the results of biomedical research in our lifetime. "

Sir Paul Nurse, Cancer Research UK

Your research papers will be:

- available free of charge to the entire biomedical community

- peer reviewed and published immediately upon acceptance

- cited in PubMed and archived on PubMed Central

- yours - you keep the copyright 